\title{
PEMBUATAN JELLY DRINK NANAS (Ananas comosus L) KAJIAN TINGKAT KEMATANGAN BUAH NANAS DAN KONSENTRASI PENAMBAHAN KARAGENAN TERHADAP SIFAT FISIK, KIMIA DAN ORGANOLEPTIK
}

\section{Making of Pineapple Jelly Drink (Ananas comosus L) Study of Pineapple Fruit Maturity Level and Concentration of Carrageenan Addition to Physical, Chemical and Organoleptic Properties}

\author{
Ressa Yowandita \\ Jurusan Teknologi Hasil Pertanian, FTP Universitas Brawijaya Malang \\ JI. Veteran, Malang 65145 \\ *Penulis Korespondensi, Email: r.yowandita@gmail.com
}

\begin{abstract}
ABSTRAK
Nanas (Ananas comosus L) telah dikenal baik oleh masyarakat Indonesia. Nanas mempunyai kontribusi $8 \%$ dari produksi buah segar di dunia, dan Indonesia merupakan negara penghasil nanas segar dan olahan terbesar ketiga setelah Thailand dan Philipina. Ke depan, salah satu peluang investasi yang terbuka adalah pengembangan industri pengolahan nanas, seperti nanas kaleng, manisan nanas, selai nanas, minuman jeli nanas dan sebagainya. Pada pembuatan jelly drink konsentrasi karagenan dan tingkat kematangan buah juga berpengaruh terhadap proses pembentukan gel. Metode yang digunakan Rancangan Acak Kelompok (RAK) dengan dua faktor. Faktor pertama yaitu tingkat kematangan buah nanas. Faktor kedua yaitu konsentrasi karagenan $(0.40 \% ; 0.70 \%$; dan $1 \%)$ Hasil penelitian menunjukkan bahwa perlakuan penambahan karagenan dan tingkat kematangan berpengaruh nyata terhadap vitamin $\mathrm{C}$, antioksidan, nilai $\mathrm{pH}$, total padatan terlarut, dan sineresis, total gula. Hasil analisis total asam, warna. Perlakuan terbaik jelly drink nanas menurut parameter fisik, kimia dan organoleptik adalah jelly drink nanas perlakuan penambahan karagenan konsentrasi $0.40 \%$ dan tingkat kematangan $100 \%$.
\end{abstract}

Kata kunci: Jelly Drink, Karagenan, Nanas, Tingkat kematangan

\section{ABSTRACT}

Pineapple (Ananas comosus $L$ ) has been well known by the people of Indonesia. Pineapple accounts for $8 \%$ of fresh fruit production in the world, and Indonesia is the third largest producer of fresh pineapple and the processed products after Thailand and the Philippines. Looking ahead, one of the open investment opportunities is the development of the pineapple processing industry, such as canned pineapple, candied pineapple, pineapple jam, pineapple jelly and so on. In the manufacture of jelly drinks the concentration of carrageenan and fruit maturity levels also affect the process of gel formation. The method used Randomized Block Design (RAK) with two factors. The first factor is the maturity level of pineapple fruit. The second factor was carrageenan concentration $(0.40 \%, 0.70 \%$, and $1 \%)$. The result showed that the addition of carrageenan and maturity level had significant effect on vitamin $C$, antioxidant, $\mathrm{pH}$ value, total dissolved solid, and sineresis, total sugar. Result of total analysis of acid, color. The best treatment of pineapple jelly drink according to physical, chemical and organoleptic parameters is jelly drink of pineapple addition of carrageenan concentration $0.40 \%$ and $100 \%$ maturity level.

Keywords: Jelly Drink, Carrageenan, pineapple, maturity level 


\section{PENDAHULUAN}

Nanas (Ananas comosus $L$ ) telah dikenal baik oleh masyarakat Indonesia. Nanas mempunyai kontribusi $8 \%$ dari produksi buah segar di dunia, dan Indonesia merupakan negara penghasil nanas segar dan olahan terbesar ketiga setelah Thailand dan Philipina.

Di Indonesia sendiri salah satu tempat penghasil nanas adalah di daerah kabupaten Blitar. Potensi areal pertanaman di Kabupaten Blitar seluas 500 hektar di lahan milik petani serta Perum Perhutani. Volume panen nanas di kawasan tersebut selama ini sekitar 40 ton50 ton per hektar ( 1 hektare $=40.000$ bibit) dalam jangka pertanaman 1,5 tahun. Buah nanas sudah dikembangkan cukup lama di Kabupaten Blitar, sehingga dalam hal budidaya petani bahkan sudah mampu mengendalikan masa panennya. Pasar utama nanas selama ini adalah untuk dikonsumsi langsung dalam bentuk buah segar. Kematangan suatu buah dapat dilihat dari sifat fisiknya yaitu dari warna dan tekstur buah tersebut. Buah nanas yang masih muda memiliki warna hijau keputihan, nanas yang setengah matang berwarna hijau lebih tua dan nanas yang sudah matang berwarna kuning hingga oranye dengan sedikit warna hijau. Ke depan, salah satu peluang investasi yang terbuka adalah pengembangan industri pengolahan nanas, seperti nanas kaleng, manisan nanas, selai nanas, minuman jeli nanas dan sebagainya.

Buah nanas berpotensi dijadikan bahan baku pembuatan jelly drink. Jelly drink merupakan salah satu bentuk produk pangan inovatif berbentuk minuman jeli dengan tingkat viskositas sedang sehingga mudah untuk dihisap dengan menggunakan sedotan. Pembuatan jelly drink cukup sederhana, yakni meliputi pemilihan bahan baku, pembuatan sari buah, pencampuran dengan bahan tambahan lain, pemanasan dan pendinginan. Bahan tambahan lain yang digunakan adalah karagenan, gula pasir, asam sitrat dan pektin jika diperlukan. Dalam pembuatan jelly drink faktor asam, gula dan pektin sangat mempengaruhi tekstur serta proses pembentukan gel dari jelly drink. Selain ketiga faktor tersebut, tingkat kematangan juga berpengaruh terhadap proses pembentukan gel karena tingkat kematangan akan berpengaruh terhadap sifat kimia dan fisik dari buah tersebut.

Informasi mengenai pengaruh tingkat kematangan buah nanas dan penambahan konsentrasi karagenan pada pembuatan jelly drink nanas yang tepat dan dikarenakan jarang yang menggunakan sari dari buah alami dari buah nanas. Penelitian lebih lanjut perlu dilakukan mengenai hal tersebut untuk inovasi produk jelly drink sebagai produk olahan yang dapat diunggulkan di daerah tersebut. Berdasarkan informasi tersebut, tingkat kematangan nanas yang berbeda dalam penelitian ini diharapkan dapat menentukan formula pembuatan jelly drink nanas yang terbaik serta konsentrasi karagenan diharapkan dapat berpengaruh terhadap tekstur jelly drink.

\section{Bahan}

\section{BAHAN DAN METODE}

Buah nanas dengan tingkat kematangan berbeda yang diperoleh dari perkebunan nanas di Desa Wisata Semen Kabupaten Blitar, Jawa Timur. Gula pasir yang diperoleh dari pasar Blimbing Malang, serta kappa karagenan. Bahan-bahan yang diperlukan untuk analisis kimia, antara lain akuades, buffer $\mathrm{pH} 4$ dan 7 , amilum $1 \%$, lodium $0.001 \mathrm{~N}$, larutan $\mathrm{NaOH} 0.10 \%$, indikator PP, etanol 95\%, larutan DPPH

Alat

Alat-alat yang digunakan adalah blender (Miyako), gelas ukur $100 \mathrm{ml}$, sendok stainless steel, pisau, baskom, kain saring, thermometer, kompor (Rinnai Ceflon) dan panci. Alat-alat yang digunakan untuk analisis fisik dan kimia meliputi timbangan analitik (Denver Instrument M310), color reader (Konica Minolta), kertas saring, glassware merk Pyrex (beaker glass 250 $\mathrm{ml}, 500 \mathrm{ml}$, erlenmeyer $100 \mathrm{ml}$, labu takar $100 \mathrm{ml}$ ), spektrofotometer (Labomed. Inc), pipet volume $10 \mathrm{ml}$, serta vortex (Turbo Mixer), Tensile Strength (IMADA), hand refraktometer (ATAGO). 


\section{Desain Penelitian}

Rancangan percobaan pada penelitian ini adalah Rancangan Acak Kelompok (RAK) dengan dua faktor. Faktor pertama yaitu tingkat kematangan buah nanas. Faktor kedua yaitu konsentrasi karagenan $(0.40 \% ; 0.70 \%$; dan $1 \%)$

\section{Tahapan Penelitian}

Disiapkan nanas sesuai tingkatan kematangan nya yang telah disortasi, karagenan $(0.40 \%$, $0.70 \%$ dan $1 \%$ ) dan gula (13\%). nanas dicuci, kemudian dikupas, lalu dipotong-potong. nanas di blanching selama 5 menit dengan suhu $\pm 80^{\circ} \mathrm{C}$. nanas ditimbang sebanyak $100 \mathrm{gram}$, kemudian dihancurkan menggunakan blender. Nanas disaring dengan kain saring dan diambil sarinya. Sari nanas ditimbang sebanyak $100 \mathrm{ml}$. Sari nanas yang telah ditimbang kemudian dicampurkan karagenan dengan konsentrasi $0.40 \%, 0.70 \%$ dan $1 \%$ dan gula pasir dengan konsentrasi $13 \%$, kemudian dimasak dan diaduk $\pm 90^{\circ} \mathrm{C}$ selama 5 menit. Jelly drink nanas dimasukkan ke dalam cup, kemudian didinginkan pada suhu ruang.

\section{Prosedur Analisisis}

Analisis dalam penelitian ini meliputi $\mathrm{pH}$ dengan $\mathrm{pH}$ meter (Yuwono dan Susanto,1998), total asam (Ranggana, 1987), total gula metode anthrone (Apriyanto, 1994), vitamin C (Sudarmadji dkk, 1997), aktivitas antioksidan metode DPPH (Hatano et al., 1998), Sineresis (Yuwono dan Susanto, 1998), tekstur kekenyalan dengan tensile strength, warna dengan colour reader (Yuwono dan Susanto, 1998), total padatan terlarut (AOAC, 1990), uji hedonik organoleptik (Rahayu, 2001) dan uji perlakuan terbaik (Zeleny, 1982).

\section{HASIL DAN PEMBAHASAN}

\section{Bahan Baku}

Data hasil analisis parameter fisik dan kimia buah terong belanda dibandingkan pustaka dapat dilihat pada Tabel 1.

Tabel 1. Data Hasil Analisis Bahan Baku dibandingkan dengan Pustaka

\begin{tabular}{lcccccc}
\hline \multirow{2}{*}{ Parameter } & \multicolumn{2}{c}{ Buah Nanas Matang 50\% } & \multicolumn{2}{c}{ Buah Nanas Matang 75\% } & \multicolumn{2}{c}{ Buah Nanas Matang } \\
\cline { 2 - 7 } & Hasil Analisis & Literatur & Hasil Analisis & Literatur & Hasil Analisis & Literatur \\
\hline $\begin{array}{l}\text { Kadar Air (\%) } \\
\text { Kadar Abu }\end{array}$ & 89.92 & $84.86^{\mathrm{a}}$ & 91.75 & $84.76^{\mathrm{a}}$ & 92.80 & $84.33^{\mathrm{a}}$ \\
$(\%)$ & 0.34 & $0.33^{\mathrm{b}}$ & 0.44 & $0.32^{\mathrm{b}}$ & 0.42 & $0.35^{\mathrm{b}}$ \\
$\begin{array}{l}\text { Total Gula } \\
(\%)\end{array}$ & 0.14 & $2.91^{\mathrm{b}}$ & 0.15 & $4.69^{\mathrm{b}}$ & 0.28 & $5.60^{\mathrm{b}}$ \\
$\begin{array}{l}\text { Total Asam } \\
(\%)\end{array}$ & 0.19 & $4.98^{\mathrm{a}}$ & 0.13 & $4.62^{\mathrm{a}}$ & 0.10 & $4.17^{\mathrm{a}}$ \\
$\begin{array}{l}\text { Antioksidan } \\
\text { IC50 (ppm) }\end{array}$ & 18.20 & - & 18.20 & - & 17.30 & - \\
$\begin{array}{l}\text { Vitamin C } \\
\text { (mg/100g) }\end{array}$ & 0.25 & $25.40^{\mathrm{b}}$ & 0.25 & $25.90^{\mathrm{b}}$ & 0.30 & $23.40^{\mathrm{b}}$ \\
$\begin{array}{l}\text { Total Pektin } \\
(\%)\end{array}$ & 0.08 & $1.64^{\mathrm{b}}$ & 0.07 & $1.08^{\mathrm{b}}$ & 0.06 & $1.02^{\mathrm{b}}$ \\
$\begin{array}{l}\text { pH } \\
\text { Warna : }\end{array}$ & 2.51 & $3.43^{\mathrm{b}}$ & 2.22 & $3.56^{\mathrm{b}}$ & 2.18 & $4.82^{\mathrm{b}}$ \\
$\begin{array}{l}\text { Kecerahan (L) } \\
\text { Kemerahan }\end{array}$ & -2.33 & - & -0.43 & - & -0.13 & - \\
$\begin{array}{l}\text { (a*) } \\
\text { Kakuningan }\end{array}$ & 27.03 & - & 28.83 & - & 22.86 & - \\
$\left(\mathrm{b}^{\star}\right)$ & 56 & - & 55.60 & - & 57.13 & - \\
\hline
\end{tabular}

Pada Tabel 1. Diketahui adanya perbedaan hasil analisis dengan literatur yang dapat disebabkan adanya perbedaan varietas nanas yang digunakan pada penelitian dengan yang 
digunakan pada pustaka. Menurut Muchtadi (1992), komponen kimia dalam tanaman dapat dipengaruhi oleh beberapa faktor antara lain: perbedaan varietas, cara pemanenan, kematangan pada waktu panen, dan kondisi penyimpanan setelah panen.

\section{Kadar Air}

Berdasarkan hasil analisis diperoleh rerata kadar air pada jelly drink nanas berkisar antara 86\%-89\%. Nilai rerata kadar air pada jelly drink nanas ditunjukkan pada Gambar 1.

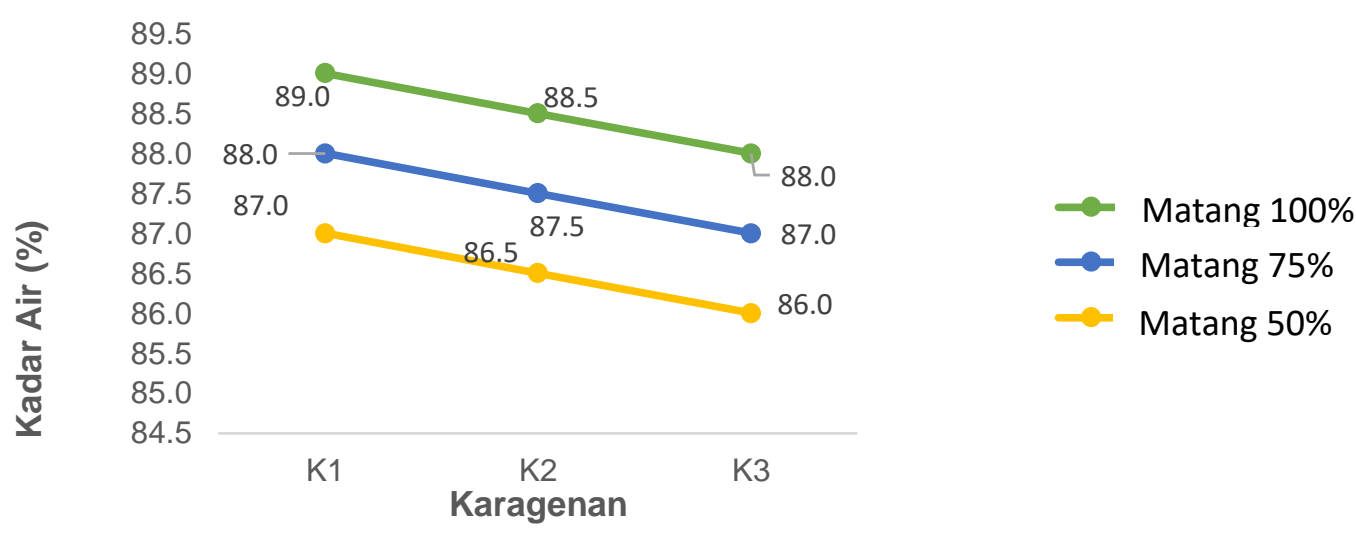

Gambar 1. Rerata Rerata kadar air Jelly Drink nanas Akibat tingkat kematangan buah nanas yang berbeda dan konsentrasi Karagenan

Menunjukkan bahwa semakin tinggi karagenan yang ditambahkan maka kadar air dalam jelly drink akan semakin menurun seiring sedangkan dengan semakin matangnya buah nanas makan kadar air akan semakin meningkat. Hal ini dapat disebabkan karena kandungan air bahan baku yang berbeda-beda pada setiap tingkat kematangan nanas. Sedangkan, semakin matang buah nanas yang digunakan sebagai bahan baku maka kadar air dalam jelly drink akan semakin meningkat.

\section{Vitamin C}

Berdasarkan hasil analisis diperoleh rerata vitamin $\mathrm{C}$ pada jelly drink nanas berkisar antara $0.44 \%$ hingga $1.85 \%$. Nilai rerata vitamin C pada jelly drink nanas ditunjukkan pada Gambar 2.

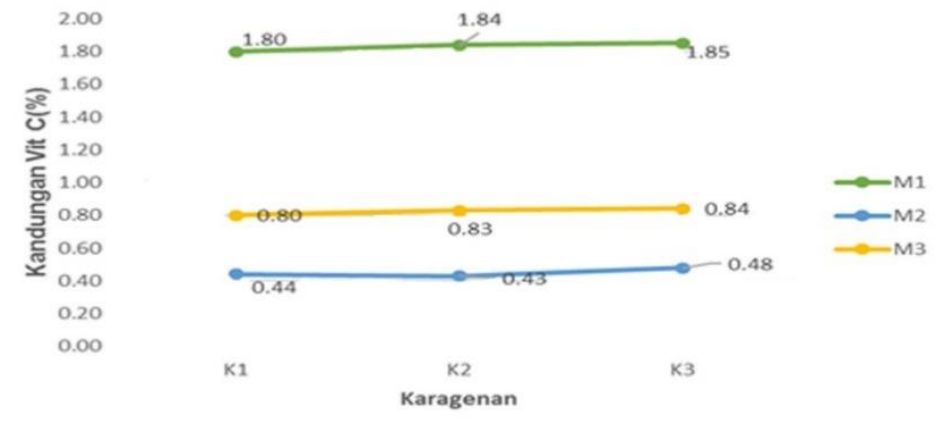

Gambar 2. Rerata Rerata vitamin C Jelly Drink nanas Akibat tingkat kematangan buah nanas yang berbeda dan konsentrasi Karagenan

Berdasarkan gambar 2 dapat diketahui Penurunan kadar vitamin $\mathrm{C}$ pada sari buah nanas disebabkan adanya pemanasan selama pengolahan (proses pemasakan) dapat menyebabkan terjadinya degradasi vitamin $C$ sehingga mampu mempercepat terjadinya oksidasi vitamin C (Winarno, 2004). Vitamin C mudah teroksidasi dan proses tersebut dipercepat oleh panas, sinar, alkali, enzim, oksidator serta oleh katalis tembaga dan besi. 
Pada proses pengolahan, kehilangan vitamin $\mathrm{C}$ akibat reaksi enzimatis jumlahnya sangat sedikit, sedangkan reaksi non-enzimatis menjadi penyebab utama hilangnya vitamin $\mathrm{C}$. Menurut Potner (1998) dalam Agustin (2013), semakin keras tekstur gel yang terbentuk akibat penambahan karagenan maka oksigen dan kofaktor-kofaktor yang dapat mempercepat oksidasi vitamin $\mathrm{C}$ akan lebih dapat dihambat. Karagenan merupakan zat yang dapat mengikat air, sedangkan vitamin $\mathrm{C}$ merupakan vitamin yang larut oleh air, maka vitamin $\mathrm{C}$ yang larut akan diikat oleh karagenan sehingga vitamin $\mathrm{C}$ akan lebih stabil ketika konsentrasi karagenan semakin tinggi (Selviana, 2016).

\section{Total Gula}

Berdasarkan hasil analisis diperoleh rerata total gula pada jelly drink nanas berkisar antara $0.21 \%$ hingga $0.53 \%$. Nilai rerata total gula pada jelly drink nanas ditunjukkan pada Gambar 3.

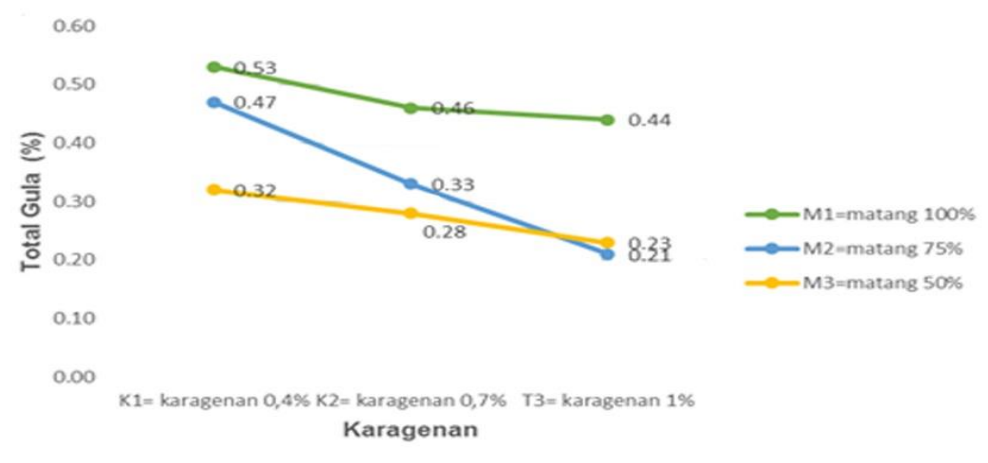

Gambar 3. Rerata Rerata total gula Jelly Drink nanas Akibat tingkat kematangan buah nanas yang berbeda dan konsentrasi Karagenan

Nilai total gula tertinggi berdasarkan Gambar 3 yaitu total gula pada jelly drink dengan perlakukan tingkat kematangan buah paling matang (matang 100\%) dan sedikit penambahan karagenan $(0.40 \%)$. Nilai total gula yang tinggi diduga karena bahan baku (nanas) yang digunakan memilki kematangan $70-80 \%$ atau complete yellow. Hal ini sesuai dengan hasil penelitian Syahrumsyah dkk. (2010) yang menyatakan bahwa tingkat kematangan buah nanas menyebabkan tingginya kadar gula yang terkandung di dalamnya semakin meningkat dan berdampak pada produk yang dihasilkan pada jelly drink tersebut. Menurut Luthony (1990) dalam Pratama, dkk. (2013), total gula dapat meningkat disebabkan adanya penurunan kadar air bahan sehingga massa bahan akan ikut berkurang dan penambahan sukrosa pada proses pembuatannya.

\section{Total Asam}

Berdasarkan hasil analisis diperoleh rerata total asam pada jelly drink nanas berkisar antara $0.48 \%$ hingga $0.71 \%$. Nilai rerata total asam pada jelly drink nanas ditunjukkan pada Gambar 4. Dapat dilihat pada Gambar 4 bahwa semakin tinggi penambahan karagenan maka total asam semakin menurun. Rerata total asam yang paling tinggi diperoleh pada perlakuan dengan penambahan karagenan sebesar $1 \%$ dan tingkat kematangan buah $100 \%$ dengan nilai total asam sebesar $0.71 \%$. Rerata total asam yang paling rendah diperoleh pada tingkat kematangan buah $75 \%$ dan penambahan karagenan sebanyak $0.40 \%$ dengan total asam sebesar $0.48 \%$. Karagenan merupakan hidrokoloid yang dapat mengikat air oleh adanya gugus $\mathrm{OH}^{-}$yang relatif banyak, sehingga menyebabkan total asam cenderung menurun. Menurut Kelco (2007), kelarutan karagenan 
dipengaruhi oleh garam yang terbentuk dari gugus sulfat ester. Adanya garam tersebut akan menurunkan total asam yang terdapat pada produk jelly drink.

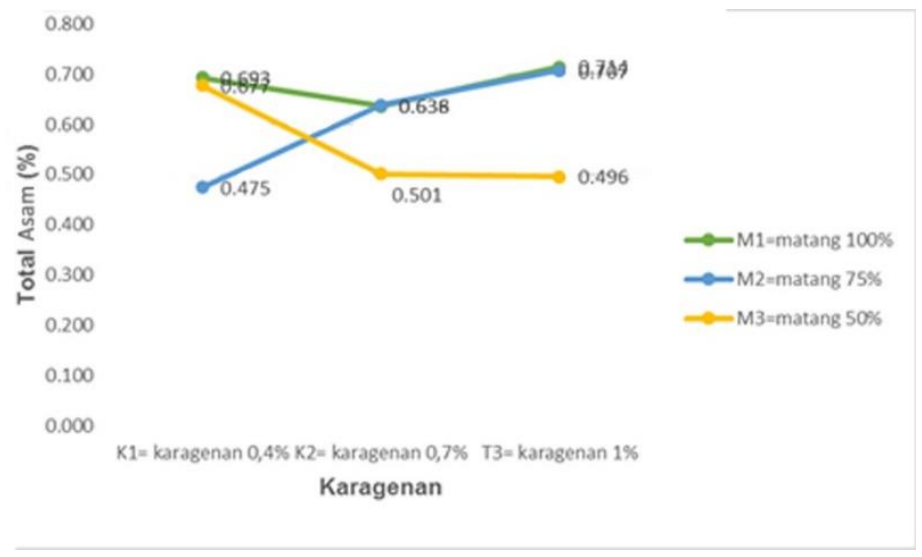

Gambar 4. Rerata Rerata aktivitas total asam Jelly Drink nanas Akibat tingkat kematangan buah nanas yang berbeda dan konsentrasi Karagenan

6. $\mathrm{pH}$

Berdasarkan hasil analisis diperoleh rerata $\mathrm{pH}$ pada jelly drink nanas berkisar antara 4.27 hingga 4.77. Nilai rerata pH pada jelly drink nanas ditunjukkan pada Gambar 5.

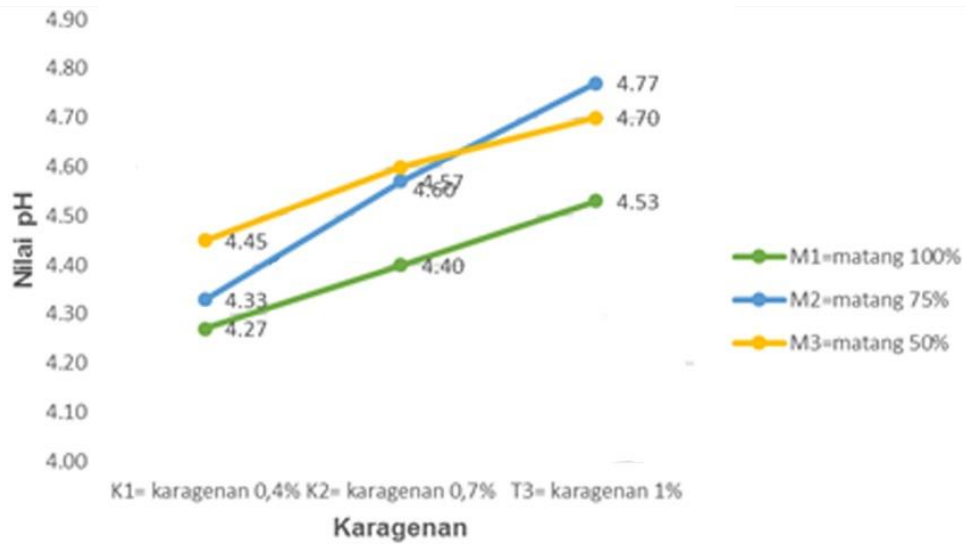

Gambar 5. Rerata Rerata pH Jelly Drink nanas Akibat tingkat kematangan buah nanas yang berbeda dan konsentrasi Karagenan

Berdasarkan grafik pada Gambar 5 terjadi peningkatan nilai $\mathrm{pH}$ akibat perlakuan yangdilakukan. Peningkatan $\mathrm{pH}$ sejalan dengan adanya penambahan air, dimana ion $\mathrm{H}^{+}$yang berasal dari asam-asam organik mengalami pengenceran, sehingga ion $\mathrm{H}^{+}$yang membentuk asam akan berkurang dan $\mathrm{pH}$ produk akan semakin meningkat. Menurut Azizah (2011), suatu zat asam yang ditambahkan ke dalam air akan mengakibatkan bertambahnya ion hidrogen $\left(\mathrm{H}^{+}\right)$dalam air dan berkurangnya ion hidroksida $\left(\mathrm{OH}^{-}\right)$, sehingga semakin bertambahnya ion hidrogen $\left(\mathrm{H}^{+}\right)$maka pH suatu zat akan semakin menurun. Semakin banyak jumlah asam yang ditambahkan dalam suatu larutan maka semakin besar pula bagian ion $\mathrm{H}^{+}$yang dilepaskan sehingga menurunkan nilai $\mathrm{pH}$. 


\section{Aktivitas Antioksidan}

Berdasarkan hasil analisis diperoleh rerata Aktivitas antioksidan pada jelly drink nanas berkisar antara $0.70 \%$ hingga $0.89 \%$. Nilai rerata aktivitas antioksidan pada jelly drink nanas ditunjukkan pada Gambar 6.

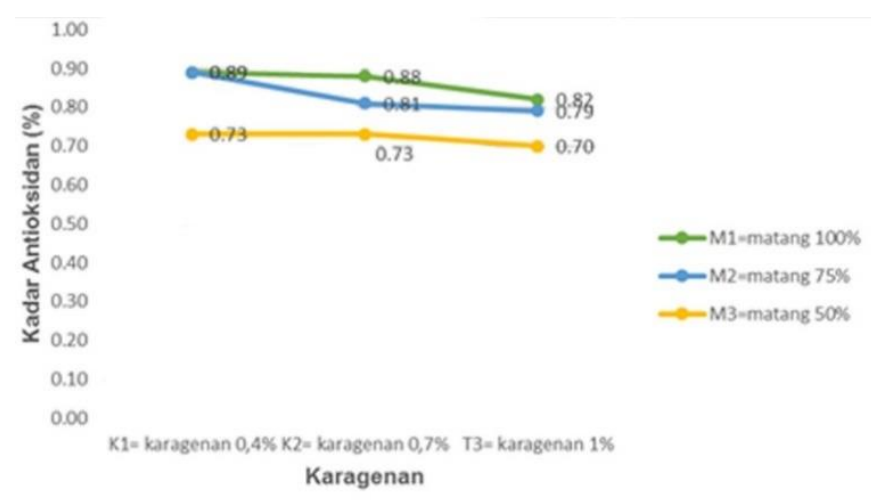

Gambar 6. Rerata Aktivitas antioksidan Jelly Drink nanas Akibat tingkat kematangan buah nanas yang berbeda dan konsentrasi Karagenan

Berdasarkan Gambar 6, Aktivitas antioksidan dapat meningkat maupun menurun diakibatkan banyak faktor. Penambahan karagenan yang meningkat menyebabkan nilai IC50 menurun, hal ini menunjukkan aktivitas antioksidan semakin tinggi. Menurut Asmarai et al. (1996) dalam Rachmayati (2017), proses pemanasan di atas suhu $70^{\circ} \mathrm{C}$ akan menurunkan aktivitas antioksidan lebih dari 10\%, sehingga nilai aktivitas antioksidan pada produk jelly drink tergolong rendah

\section{Total Padatan Terlarut}

Berdasarkan hasil analisis diperoleh rerata Total Padatan Terlarut pada jelly drink nanas berkisar antara $16.80 \%$ sampai $21 \%$. Nilai rerata Total Padatan Terlarut pada jelly drink nanas ditunjukkan pada Gambar 7.

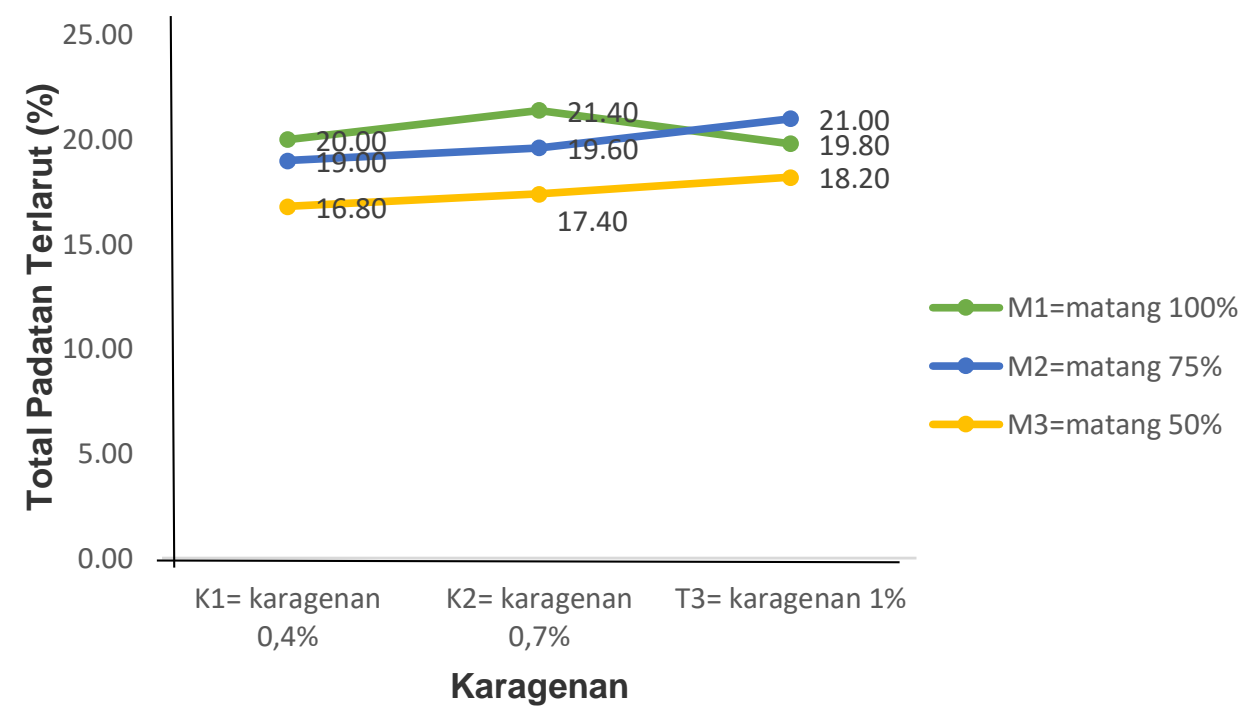

Gambar 7. Rerata Rerata total padatan terlarut Jelly Drink nanas Akibat tingkat kematangan buah nanas yang berbeda dan konsentrasi Karagenan

Gambar 7 menunjukkan bahwa semakin tinggi proporsi karagenan yang ditambahkan maka total padatan terlarut dalam jelly drink akan semakin meningkat seiring dengan semakin matangnya buah nanas. Hal ini dikarenakan gula memiliki daya larut yang tinggi sehingga kandungan padatan terlarut akan semakin tinggi seiring dengan semakin banyaknya proporsi 
penambahan gula yang ditambahkan (Buckle et al., 2009). Besarnya nilai total padatan terlarut menunjukkan banyaknya jumlah padatan organik yang terlarut dalam sari buah. Hasil analisis sidik ragam (ANOVA) menunjukkan bahwa perlakuan tiga tingkat kematangan nanas tidak memberikan pengaruh yang nyata sedangkan proporsi penambahan karagenan memberikan pengaruh berbeda nyata $(\alpha<0.05)$ terhadap total padatan terlarut jelly drink nanas, namun tidak terjadi interaksi diantara kedua faktor.

\section{Tingkat Kecerahan $\left(L^{*}\right)$}

Berdasarkan hasil analisis diperoleh rerata tingkat kecerahan $\left(\mathrm{L}^{*}\right)$ pada jelly drink nanas berkisar antara $55.20-64.90$. Nilai rerata tingkat kecerahan $\left(L^{*}\right)$ pada jelly drink nanas ditunjukkan pada Tabel 2.

Tabel 2. Rerata Rerata Tingkat Kecerahan $\left(L^{*}\right)$ Jelly Drink nanas Akibat tingkat kematangan buah nanas yang berbeda dan konsentrasi Karagenan

\begin{tabular}{|c|c|c|c|}
\hline \multicolumn{3}{|c|}{ Perlakuan } & \multirow{2}{*}{$\begin{array}{l}\text { Rata-rata } \\
\pm(\%)\end{array}$} \\
\hline Kode & $\begin{array}{l}\text { Kematangan } \\
(\%)(\mathrm{M})\end{array}$ & $\begin{array}{l}\text { Karagenan } \\
(\%)(\mathrm{K})\end{array}$ & \\
\hline M1K1 & 100 & 0.40 & 57.91 \\
\hline M1K2 & 100 & 0.70 & 55.70 \\
\hline M1K3 & 100 & 1.00 & 53.13 \\
\hline M2K1 & 75 & 0.40 & 55.26 \\
\hline M2K2 & 75 & 0.70 & 60.70 \\
\hline M2K3 & 75 & 1.00 & 64.90 \\
\hline M3K1 & 50 & 0.40 & 59.04 \\
\hline M3K2 & 50 & 0.70 & 62.27 \\
\hline M3K3 & 50 & 1.00 & 57.15 \\
\hline
\end{tabular}

Hasil analisis keragaman menunjukkan bahwa penambahan karagenan yang berbeda dan otingkat kematangan buah nanas yang digunakan untuk bahan baku pembuatan jelly drink serta interaksi keduanya tidak memberikan pengaruh yang nyata $(\alpha>0.05)$ terhadap kecerahan jelly drink. Karagenan tidak memberikan pengaruh yang nyata terhadap kecerahan jelly drink drink nanas hal ini disebabkan selisih penambahan karagenan yang tidak terlalu besar.

\section{Tingkat Kemerahan ( $\left.a^{*}\right)$}

Berdasarkan hasil analisis diperoleh rerata tingkat kemerahan pada $\left(\mathrm{a}^{*}\right)$ jelly drink nanas berkisar antara $-0.80--3.20$. Nilai a menyatakan warna kromatik campuran merah dan hijau. Rerata kemerahan jelly drink drink nanas berkisar -0.80 - -3.20 tingkat kematangan buah dan penambahan karagenan yang berbeda tidak berpengaruh terhadap kemerahan jelly drink drink nanas, hal ini diduga karena bahan penyusun jelly drink nanas seperti nanas dan karagenan tidak menyumbangkan warna merah. Warna nanas adalah kuning hingga orange sedangkan karagenan berwarna putih (Camus Camus, 2004).

\section{Tingkat Kekuningan ( $\left.b^{*}\right)$}

Berdasarkan hasil analisis diperoleh rerata tingkat kekuningan pada $\left(b^{*}\right)$ jelly drink nanas berkisar antara 5.70 - 13.25. Nilai rerata tingkat kekuningan $\left(b^{*}\right)$ pada jelly drink nanas ditunjukkan pada Tabel 3.

Tabel 3. Rerata Rerata Tingkat Kekuningan $\left(b^{*}\right)$ Jelly Drink nanas Akibat tingkat kematangan buah nanas yang berbeda dan konsentrasi Karagenan

Hasil analisis keragaman menujukkan bahwa penambahan karagenan yang berbeda dan interaksi keduanya tidak memberikan pengaruh yang nyata $(\alpha>0.05)$ terhadap kekuningan jelly drink drink nanas. Karagenan tidak memberikan kontribusi langsung terhadap warna kuning, sebab karagenan memiliki warna putih (Kelco, 2007). 


\begin{tabular}{c|l|l|l}
\hline \multicolumn{2}{c|}{ Perlakuan } & \multirow{2}{*}{$\begin{array}{l}\text { Rata-rata } \\
\mathbf{( \% )}\end{array}$} \\
\cline { 1 - 3 } Kode & $\begin{array}{l}\text { Kematangan } \\
(\%)(\mathbf{M})\end{array}$ & $\begin{array}{l}\text { Karagenan } \\
(\%)(\text { K) }\end{array}$ & \\
\hline M1K1 & 100 & 0.40 & 13.30 \\
M1K2 & 100 & 0.70 & 15.54 \\
M1K3 & 100 & 1.00 & 14.95 \\
M2K1 & 75 & 0.40 & 10.53 \\
M2K2 & 75 & 0.70 & 10.95 \\
M2K3 & 75 & 1.00 & 8.60 \\
M3K1 & 50 & 0.40 & 7.74 \\
M3K2 & 50 & 0.70 & 7.51 \\
M3K3 & 50 & 1.00 & 5.70 \\
\hline
\end{tabular}

12. Sineresis

Berdasarkan hasil analisis diperoleh rerata sineresis jelly drink nanas berkisar antara $0.16 \%$ hingga $0.24 \%$. Nilai rerata sineresis pada jelly drink nanas ditunjukkan pada Tabel 4.

Tabel 4. Rerata Rerata sineresis Jelly Drink nanas Akibat tingkat kematangan buah nanas yang berbeda dan konsentrasi Karagenan

\begin{tabular}{l|l|l|l}
\hline \multicolumn{3}{c|}{ Perlakuan } & $\begin{array}{l}\text { Rata-rata } \\
\mathbf{( \% )}\end{array}$ \\
\cline { 1 - 3 } Kode & $\begin{array}{r}\text { Kematangan } \\
(\%)(\mathrm{M})\end{array}$ & $\begin{array}{l}\text { Karagenan } \\
(\%)(\mathrm{K})\end{array}$ & \\
\hline M1K1 & 100 & 0,4 & 0,24 \\
M1K2 & 100 & 0,7 & 0.19 \\
M1K3 & 100 & 1,0 & 0,16 \\
M2K1 & 75 & 0,4 & 0,21 \\
M2K2 & 75 & 0,7 & 0,21 \\
M2K3 & 75 & 1,0 & 0,12 \\
M3K1 & 50 & 0,4 & 0,22 \\
M3K2 & 50 & 0,7 & 0,20 \\
M3K3 & 50 & 1,0 & 0,16 \\
& & & \\
\hline
\end{tabular}

Berdasarkan Tabel 4 Penambahan karagenan yang berbeda memberikan pengaruh yang berbeda nyata terhadap tingkat sineresis jelly drink buah nanas. Penambahan karagenan yang meningkat mengakibatkan sineresis semakin menurun. Bahan pembentuk gel akan membentuk jaringan tiga dimensi bersama air dalam kondisi yang sinergis, dengan terbentuknya jaringan tiga dimensi maka molekul air akan terjebak dan tidak mudah keluar jaringan. Semakin tinggi angka sineresis berarti semakin banyak jumlah air yang keluar yang berarti semakin sedikitnya atau lemahnya struktur tiga dimensi yang terbentuk (Febriyanti, 2015). Pada jelly drink komersial memiliki sineresis $1.36 \mathrm{mg} / \mathrm{menit}$. Perbedaan sineresis tersebut disebabkan karena gelling agent yang digunakan berbeda sehingga gel yang terbentuk memiliki kekuatan struktur tiga dimensi yang berbeda.

\section{Analisis Organoleptik}

Hasil analisis metode uji kesukaan (Hedonic Scale Scoring) menunjukkan bahwa perlakuan penambahan karagenan dan penambahan gula pasir berpengaruh nyata ( $p$-value $<0.05$ ) terhadap tingkat kesukaan panelis pada tekstur (daya hisap), rasa, aroma, dan warna jelly drink nanas.

\section{Perlakuan Terbaik}

Hasil pengujian perlakuan terbaik jelly drink terong belanda terhadap parameter kimia, fisik dan organoleptik dapat dilihat pada Tabel 5.

Tabel 5. Perlakuan Terbaik Kimia, Fisik dan Organoleptik Jelly drink nanas Akibat tingkat kematangan buah nanas yang berbeda dan konsentrasi Karagenan 


\section{Perlakuan}

Nilai L Total Terendah

(Metode Zeleny)

Kimia, fisik dan Organoleptik

$\begin{array}{ll}\text { M1K1 (Matang 100\% dan karagenan 0.40\%) } & 0.07^{\star} \\ \text { M1K2 (Matang 100\% dan karagenan 0.70\%) } & 0.09 \\ \text { M1K3 (Matang 100\% dan karagenan 1.00\%) } & 0.14 \\ \text { M2K1 (Matang 75\% dan karagenan 0.40\%) } & 0.30 \\ \text { M2K2 (Matang 75\% dan karagenan 0.70\%) } & 0.28 \\ \text { M2K3 (Matang 75\% dan karagenan 1.00\%) } & 0.25 \\ \text { M3K1 (Matang 50\% dan karagenan 0.40\%) } & 0.29 \\ \text { M3K2 (Matang 50\% dan karagenan 0.70\%) } & 0.35 \\ \text { M3K3 (Matang 50\% dan karagenan 1.00\%) } & 0.27\end{array}$

Berdasarkan Tabel 5 dapat diketahui bahwa perlakuan terbaik kimia, fisik dan organoleptik terletak pada jelly drink terong belanda dengan perlakuan penambahan karagenan dengan konsentrasi $0.40 \%$ dan tingkat kematangan $100 \%$.

\section{SIMPULAN}

Produk jelly drink nanas terbaik menurut parameter fisik dan kimia adalah buah nanas dengan tingkat kematangan sangat matang (100\%) dengan proporsi penambahan karagenan $0.40 \%$, dengan nilai kadar air $(89 \%)$, vitamin C $(1.80 \mathrm{mg} / 100 \mathrm{~g})$, total gula $(0.54 \%)$, total asam (0.64\%), pH (4.70), antioksidan IC50 (0.89 ppm), sineresis $(0.25 \mathrm{~g} / \mathrm{menit})$. Perlakuan terbaik pembuatan jelly drink nanas menurut parameter organoleptik dengan nilai warna jelly drink nanas 5.42 (agak menyukai), aroma jelly drink nanas 5.27 (agak menyukai), rasa jelly drink nanas 5.42 (agak menyukai) dan tekstur (daya hisap) jelly drink nanas 5.37 (agak menyukai).

\section{DAFTAR PUSTAKA}

Agustin, F. 2013. Pembuatan Jelly Drink Belimbing Wuluh (Averrhoa blimbi L.) (Kajian Proporsi Belimbing Wuluh:Air dan Konsentrasi Karagenan). Skripsi. Jurusan Teknologi Hasil Pertanian. FakultasTeknologi Pertanian. Universitas Brawijaya. Malang

AOAC. 1995. Official Methodes of Analysis of The AOAC. Washington. USA

Apriyantono, A., D. Fardiaz, N.L. Puspitasari, Sedarnawati, S. Budiyanto.1994. Analisis Pangan. PAU Pangan dan Gizi. IPB Press. Bogor

Febriyanti, S. 2015. Pengaruh Konsentrasi Karagenan dan Rasio Sari JaheEmprit (Zingiber officinale var. Rubrum) terhadap Sifat Fisik, Kimia,dan Organoleptik Jelly Drink Jahe.

Skripsi. Jurusan Teknologi Hasil Pertanian. Fakultas Teknologi Pertanian. Universitas Brawijaya. Malang

Hatono, T., Kagawa, H., Yasuhara and T. Okuda. 1998. Two New Flavonoids and Other Continuens in Licorice Root: Their Relative Astringency and radical Scavenging Effect. Chem Pharm Bull 36:2090-7

Kelco, C.P. 2007. Carragenan. Dilihat pada tanggal 04 juli 2016. http://www.cpkelco.com/carragenan/product_infortaiment.html 
Muchtadi, D. 1992. Pengolahan Hasil Pertanian. Dept. Teknologi Hasil Pertanian, Fatemeta. Bogor: IPB

Rachmayati, H. 2017. Pengaruh Tingkat Kematangan Buah Belimbing (Averrhoa carambola L.) dan Proposi Penambahan Gula terhadap Karakteristik Fisik, Kimia dan Organoleptik Jelly Drink Mengandung Karaginan. Skripsi. Jurusan Teknologi Hasil Pertanian. Fakultas Teknologi Pertanian. Universitas Brawijaya. Malang

Rahayu, W.P. 2001. Penuntun Praktikum Penilaian Organoleptik. Jurusan Teknologi Pangan dan Gizi. Fakultas Teknologi Pertanian. IPB. Bogor

Ranggana, S. 1979. Manual of Analysis of Fruit and Vegetable Products. McGrawHill. New Delhi

Selviana, S. 2016. Pengaruh Konsentrasi Karagenan dan Gula Pasir terhadap Karakteristik Minuman Jelly Black Mulberry (Morus nigra L.). Skripsi. Fakultas Teknik. Universitas Pasundan. Bandung

Sudarmadji, S., Haryono, B., dan Suhardi.1997. Prosedur Analisis Untuk Bahan Makanan dan Hasil Pertanian.Penerbit Liberty dan PAU UGM. Yogyakarta

Winarno, F.G. 2004. Kimia Pangan dan Gizi. Penerbit PT Gramedia Pustaka Utama. Jakarta

Yuwono, S.S dan T. Susanto. 1998. Pengujian Fisik Pangan. Fakultas Teknologi Pertanian Universitas Brawijaya. Malang

Zeleny, M. 1982. Multiple Criteria Decision Making. McGraw Hill. New York 